\title{
Acute myocardial infarction in sickle cell anaemia associated with severe hypoxia
}

\author{
S.T.O. Saad, V.R. Arruda, O.O.M.D. Junqueira, F.A. Schelini \\ and O.B. Coelho
}

Department of Clinical Medicine, State University of Campinas, UNICAMP, C.P. 6198, CEP 13081, Campinas S.P., Brazil

\begin{abstract}
Summary: A 17 year old boy with sickle cell anaemia presented with acute myocardial infarction associated with severe hypoxia and reticulocytopenia. Ischaemic heart disease is rare in sickle cell anaemia and in this case it is possible that the acute episode of hypoxia led to myocardial infarction.
\end{abstract}

\section{Introduction}

Abnormalities of the cardiovascular system are common in patients with sickle cell anaemia. These abnormalities include a hyperkinetic circulation, systolic and diastolic murmurs, ${ }^{1-3}$ diastolic gallops, cardiomegaly on chest X-ray, ${ }^{4}$ biventricular hypertrophy ${ }^{2,5}$ and resting left ventricular performance consistent with a high output state. ${ }^{6}$ Orthopnoea, pulmonary rates and pedal oedema have also been described in the late stages of the disease. ${ }^{7}$

Although thrombotic complications are frequent in patients with sickle cell anaemia, ischaemic heart disease is excessively rare $^{8}$ perhaps because few patients demonstrate the risk factors commonly observed in the general population. Obesity is uncommon, serum cholesterol levels lower than in age-matched controls ${ }^{9}$ and, until recently, a relatively small proportion of sickle cell anaemia patients reached the age at which myocardial infarction is common in the general population.

We describe the case of a young man with sickle cell anaemia who had an acute myocardial infarction associated with an episode of severe hypoxia.

\section{Case report}

Sickle cell anaemia was diagnosed in a 4 year old boy, based on clinical, familial and laboratory data, including electrophoresis on cellulose acetate at $\mathrm{pH} 8.9^{10}$ and citrate-agar gel, ${ }^{11}$ solubility test, ${ }^{12}$ estimation of $\mathrm{Hb} \mathrm{F}^{13}$ and $\mathrm{Hb} \mathrm{A}_{2}{ }^{11}$ At 17 years old, he was admitted to hospital with a 12-hour history of severe chest pain. For almost a week he had been

Correspondence: Professor S.T.O. Saad, M.D Accepted: 29 May 1990 feeling weak with fatigue and palpitations. Physical examination revealed severe anaemia, jaundice, hepatomegaly and healed leg ulceration. Haemog lobin concentration, which was usually $8.5 \mathrm{~g} / \mathrm{dl}$, was $2.9 \mathrm{~g} / \mathrm{dl}$; red cell count was $1.1 \times 10^{9} / 1$ haematocrit was $9 \%$; mean corpuscular volume was $82 \mathrm{fl}$; mean corpuscular haemoglobin was $26.9 \mathrm{pg}$; mean corpuscular haemoglobin concentration was $32.2 \mathrm{~g} / \mathrm{dl}$ and reticulocyte count, usually $13 \%$, was $0.2 \%$; leucocyte count was $6.7 \times 10^{9} / 1$ with $15 \%$ band forms, $66 \%$ polymorphonuclears, $17 \%$ lymphocytes and $2 \%$ monocytes; platelet count was $560 \times 10^{9} / 1$. Myelogram and bone marrow biopsy were performed 5 days after the admission and demonstrated normal cellularity with myeloid: erythroid ratio $=0.8$. Erythroblastic series was hyperplastic with normal maturation, light dyserythropoiesis and no megaloblastic changes. Granulocytic series and megakaryocytes were normal. Blood group alloantibodies and auto-antibodies were negative. Creatine kinase 'myocardial specific' (CK-MB) 24 hours after the admission was $173 \mathrm{U} / 1$ (normal values $=10 \mathrm{U} / \mathrm{l}$ ) and at 36 hours was $63 \mathrm{U} / \mathrm{l}$. The electrocardiogram (ECG) showed sinus tachycardia (120 beats/min), abnormal $Q$ waves with ST elevations in leads $D_{1}$ and $\mathrm{aVL}$ and ST depression in leads $\mathrm{D}_{2}, \mathrm{D}_{3}$, avF, $V_{3}, V_{4}$ and $V_{5}$, a lateral wall infarction was diagnosed (Figure 1a). Forty-eight hours later and at follow-up after the subsequent 12 months the ECG showed abnormal $Q$ waves in leads $D_{1}$ and $a V L$ (Figure 1b). Cardiac catheterization disclosed normal coronary arteries, increased left ventricular diastolic volume and severe antero-apical akinesia. He responded well to conservative therapy for myocardial infarction and red cell transfusion. Recovery was uneventful and the patient was discharged 10 days after. 


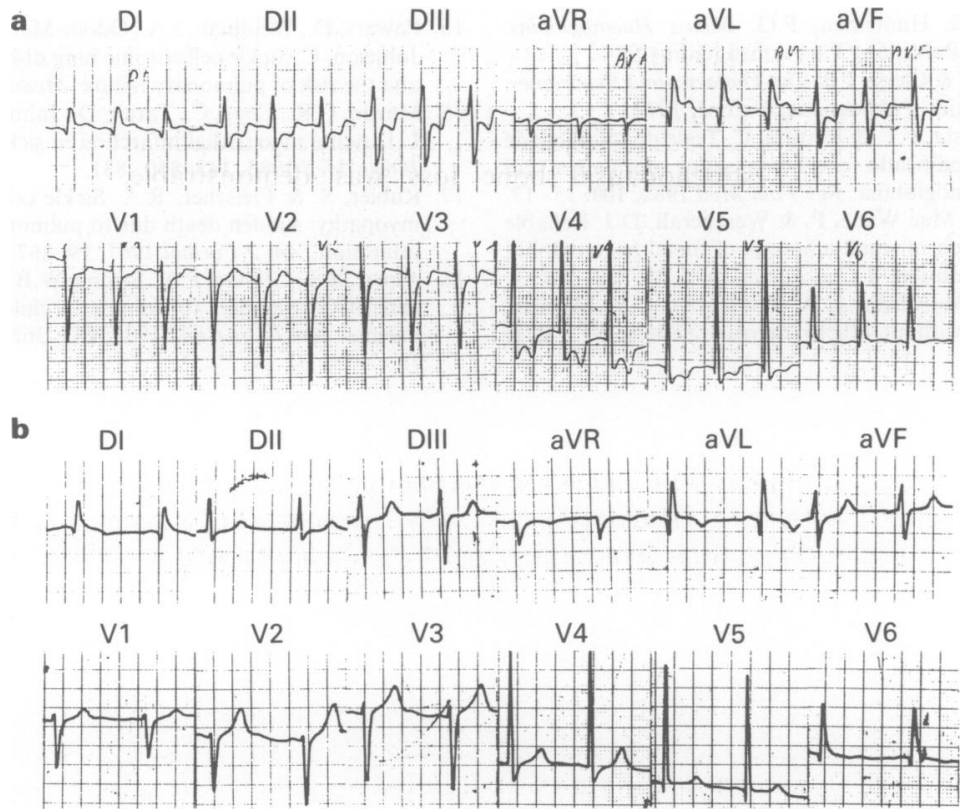

Figure 1 Electrocardiogram of the patient with sickle cell anaemia: (a) initial diagnosis of acute myocardial infarction; (b) 2 days after.

\section{Discussion}

In this case, the reticulocytopenia suggests that the episode of hypoxia was due to aplastic crisis or pure red cell aplasia. This was not observed at bone marrow examination because biopsy and myelogram were performed several days after the admission. Probably, this was not a megaloblastic crisis since there was lack of macrocytosis at blood smear.

Factors that lead to a disproportion between myocardial oxygen supply and demand results in myocardial ischaemia and infarction. ${ }^{13}$ Any problem resulting in hypoxia and failure to deliver adequate oxygen to the myocardium over a prolonged period can cause myocardial infarction, for example, thyrotoxicosis, and shock. ${ }^{14}$

\section{References}

1. Klinefelter, H.F. The heart in sickle cell anemia. Am $J$ Med Sci 1942, 203: 34-51.

2. Uzsoy, N.K. Cardiovascular findings in patients with sickle cell anemia. Am J Cardiol 1964, 13: 320-328.

3. Ng, M.L., Liebman, J., Anslovar, J. \& Gross, S. Cardiovascular findings in children with sickle cell anemia. Dis Chest 1967, 52: 788-799.

4. Shubin, H., Kaufman, R., Shapiro, M. \& Levison, P.E. Cardiovascular findings in children with sickle cell anemia. Am J Cardiol 1960, 6: 875-885.

5. Balfour, I.C., Covitz, W., Davis, H., Rao, P.S., Strong, W.B \& Alpert, B.S. Cardiac size and function in children with sickle cell anemia. Am Heart $J$ 1984, 108: 345-350.
Powars et al. ${ }^{15}$ studied a young adult population with sickle cell anaemia and suggested that myocardial ischaemia, without coronary artery disease, was a contributor to the immediate death of the patients. Multifocal myocardial fibrosis, papillary muscle necrosis and segmental infarction were observed in $40 \%$ of the cases. Based on this finding, they believed that many past instances of unexplained 'sudden death syndrome' were acute episodes of myocardial ischaemia secondary to unrecognized sickle cell chronic lung disease and cor pulmonale. ${ }^{16,17}$ On the other hand, a large proportion of children with sickle cell anaemia have ECG evidence of myocardial ischaemia during exercise. ${ }^{18}$ Therefore, in this study it is possible that the patient had previous myocardial ischaemia and the acute episode of hypoxia led to myocardial infarction.

6. Willens, H.J., Lawrence, C., Frishman, W.H. \& Strom, J.A. A noninvasive comparison of left ventricular performance in sickle cell anaemia and chronic regurgitation. Clin Cardiol 1983, 6: 542-548.

7. Garry, J.L., Bulkley, B.H. \& Hutchins, G.M. Clinicopathologic analysis of cardiac dysfunction in 52 patients with sickle cell anemia. Am J Cardiol 1978, 42: 211-216.

8. Barrett, O'N., Saunders, D.E., McFarland, D.E. \& Humphries, J.O'N. Myocardial infarction in sickle cell anemia. Am J Hematol 1984, 16: 139-147.

9. Serjeant, G.R. Sickle Cell Disease. Oxford University Press, Oxford, 1985, pp. 138-149. 
10. Lehmann, H. \& Huntsman, P.G. Man's Haemoglobins. North-Holland Publishing Co., Amsterdam, 1974.

11. Weatherall, D.J. \& Clegg, J.B. The Thalassaemia Syndromes. Blackwell Scientific Publications, Oxford, 1972.

12. Zago, M.A., Costa, F.F. \& Bottura, C. Teste de solubilidade quantitativo modificado em hemolisados normais e em variantes da hemoglobina. Rev Paul Med 1982, 100: 15-17.

13. Pembrey, M.E., Mac Wade, P. \& Weatherall, D.J. Reliable routine estimation of small amounts of foetal haemoglobin by alkali denaturation. J Clin Pathol 1972, 25: 738-740.

14. Cheitlin, M.D., McAllister, H.A. \& de Castro, C.M. Myocardial infarction without atherosclerosis. JAMA 1975, 231: 951-959.
15. Powars, D., Weidman, J.A., Odom-Maryon, T., Niland, J. \& Johnson, C. Sickle cell chronic lung disease: prior morbidity and the risk of pulmonary failure. Medicine 1988, 67: 66-76.

16. Martin, C.R., Cogg, C., Tatter, D., Johnson, C. \& Haywood, L.J. Acute myocardial infarction in sickle cell anemia. Arch Intern Med 1983, 143: 830-831.

17. Rubler, S. \& Fleischer, R.A. Sickle cell states and cardiomyopathy: sudden death due to pulmonary thrombosis and infarction: Am J Cardiol 1967, 19: 867-873.

18. Alpert, B.S., Gilman, P.A., Strong, W.B. et al. Hemodynamic and ECG responses to exercise in children with sickle. cel anemia. Am J Dis Child 1981, 153: 362-366. 